Research.

\title{
THE EFFECT OF WORKING CAPITAL MANAGEMENT ON PROFITABILITY IN MANUFACTURING COMPANY LISTED IN INDONESIA STOCK EXCHANGE
}

\author{
Yuli Anwar \\ STIE Binaniaga, Bogor, Indonesia
}

Received: January 23, 2018; Accepted: April 9, 2018; Published: June 30, 2018

To cite this article: Yuli Anwar, The Effect of Working Capital Management on Profitability in Manufacturing Company Listed in Indonesia Stock Exchange, The Accounting Journal of BINANIAGA, Vol. 03, No. 01, June 2018, pp. 01-14.

\begin{abstract}
Profitability of manufacturing companies in Indonesia is influenced by various financial factors that can be measured using financial ratios. The purpose of this study is to analyze the effect of cash turnover, average collection period of receivables, and inventory turnover to profitability on manufacturing companies listed on the Indonesia Stock Exchange. The population of this research is manufacturing company of consumer goods industry sector listed in Indonesia Stock Exchange period 2011-2015 period. Sampling method used was purposive sampling and 23 companies were obtained as sample. The method of analysis used is multiple regression analysis. Based on the result of $t$ test, cash turnover is positively related and significant to profitability. While the average collection period of receivables has a negative and significant impact on profitability. Inventory turnover has no significant effect on profitability. The results simultaneously with $F$ test show that all independent variables have significant effect to ptofitability. The adjusted $R$ square value of 0.135 indicates that $13.5 \%$ profitability can be explained by independent variables of cash turnover, average collection period and inventory turnover. While the rest of $86.5 \%$ is explained by other variables.
\end{abstract}

Keywords: Return on investment, cash turnover, average collection period and inventory turnover.

\section{INTRODUCTION}

The current era of globalization of technology is increasing and more and more similar companies are emerging making the competition in the business world increasingly tight. This makes management matters more complex. Especially with the condition of the Indonesian economy is not yet stable, thus making many companies difficult to maintain its survival. Based on this the existing companies are required to constantly develop various business strategies.

The main purpose of the company in general is to gain the maximum profit or profit. For a company to earn the maximum profit possible, it can be done by increasing the amount of production that can be sold. One of the most important production factors is the working capital the company uses to finance the company's operations to ensure the survival of the company. In achieving company goals, most of the time financial managers are allocated to working capital management. Good working capital management is very important in the field of finance because of mistakes and mistakes in managing working capital may result in business activities become stunted or stalled altogether. So that the analysis of working capital is very important to do to know the situation of working capital at the moment, then it is connected with the financial situation 
that will be faced in the future. From this information can be determined what programs should be made or what steps should be taken to overcome them.

Use and management of good working capital is one key to success in an effort to continue to move in producing goods and services. If the company can not maintain a satisfactory level of working capital then it is likely that the company will be in an unsafe condition. Working capital condition is one of the description whether the company operates in accordance with financial feasibility according to existing activities and the company does not have financial difficulties. Working capital has a flexible nature, the size of working capital can be increased or reduced according to company needs. Setting working capital should be utilized as efficiently as possible. According Mardiyanto (2009) states that: Working capital has a flexible nature, the amount of working capital can be added "Work capital policy covers two things: the amount of current assets desired and how the current assets will be financed. Reconciled with trade off between liquidity and profitability, working capital capital policy aims at achieving an optimum mix between liquidity and profitability. In other words, working capital policy is intended to achieve a certain level of profitability in accordance with the level of risk that the company is willing to bear."

If the company decides to set up large amounts of working capital, it is likely that the level of liquidity will be maintained but the opportunity to generate large profits will decrease which ultimately affects the decline in profitability. Conversely, if the company wants to maximize profitability, it may affect the level of corporate liquidity. The higher the liquidity, the better the company's position in the eyes of creditors. Therefore there is a greater possibility that the company will be able to pay its obligations on time.

In addition, the determination of the source of funds is also an important problem that must be faced by the company. Determination of funding sources can be met from internal sources of companies such as withdrawal of capital through the sale of shares to the public or from retained earnings that can eventually be reused into capital. In addition to internal funding sources, funding sources can also be met from external sources such as borrowing funds from creditors or issuing bonds offered to the public. If the company uses more debt than its own capital, this can lead to a decrease in profitability as interest expense payable to creditors also increases. So if the company decides to increase the amount of its debt, this means increasing financial risk. Moreover, if the company can not manage funds from the debt well it will have a negative impact and lower profitability. Conversely, if the company can manage the funds properly and can be used for investments in productive projects, it will have a positive impact and can increase profitability.

Profitability is a company's ability to earn profits during a certain period. Profitability as a company's ability to earn profits in relation to sales, total assets and capital itself is often used to measure the efficiency and effectiveness of the use of working capital in a company by comparing the profit with working capital used in operations. By looking at the level of profitability and working capital of a company from year to year, can know whether there is an increase or decrease the level of profit and working capital of a company.

Every company in running its business always require sufficient working capital. The existence of working capital is very important for the company to support all its activities. With the efficiency and effectiveness of working capital, the company is expected to increase profitability. The efficiency of working capital is the accuracy of the way (business and work) in running something that does not waste time, energy, cost and usefulness related to the use of working capital is to make the available working capital is not excess and not too short. To be able to determine the amount of efficient working capital, first measured from the elements of working capital.

In the management of working capital needs to be considered three main elements of working capital, namely cash, accounts receivable and inventory. Cash is one of the highest working capital elements of its liquidity level. The greater the amount

Yuli Anwar: The Effect of Working Capital Management on Profitability in Manufacturing Company Listed in Indonesia Stock Exchange 
of cash owned by the company the higher the level of liquidity. This means that the company has a smaller risk of not being able to meet its financial obligations. But that does not mean companies have to maintain a large amount of cash inventory, because the greater the cash will lead to a lot of unemployed money, which will reduce profitability. According to H. G. Guthman in Riyanto (2011), namely that "the amount of cash that should be maintained by the company is not less than $5 \%$ to $10 \%$ of total current assets" and in bankin sector Anwar and Etty (2017), revealed that or high level of influence between Non Performing Loan (NPL) and Capital Adequacy Ratio (CAR) as independent variable to Return on Assets (ROA).

In working capital, the company must also manage the accounts receivable. Management must be able to make policies regarding the collection of accounts receivable. These policies can help the company in charging its receivables on time. Managers must analyze whether a billing issue occurs. The collection period of receivables will have an impact on the profitability of the company. By knowing the time it takes the company to collect its receivables, the company can know also how far the company's policy can support effectively in the collection of accounts receivable. If a company takes too long to collect receivables then there will be an excessive investment in the receivables and this will be bad for the company because it is possible that the collectible receivables are difficult to be realized. It can decrease profitability.

Inventory is one part of working capital. Often inventory is part of a current asset that has a considerable quantity and requires special attention. Most companies maintain a level of inventory at a certain level. This happens because the company wants to have enough inventory to keep the company's sales going. "If the supply is not sufficient, then there may be a decrease in sales volume below the level that can be achieved". (Subramarnyam and Wild, 2010).

\section{Subramarnyam and Wild, 2010 stated that:}

"Management is managing the company's inventory as well as possible so that the sales activities of the company can run well. Excessive investment in inventory results in companies faced with various costs such as storage costs, insurance costs, tax costs, financial costs and physical damage to the inventory itself ".

When these costs have a substantial portion then these costs will reduce profitability. Excessive investment in inventories identifies a problem in inventory management. It is possible that the company's products do not sell well, so the inventory accumulates. It is unlikely that the goods can identify that sales policies should be improved so that the inventory can be sold by the company.

In the company required the proper management of working capital because the management of working capital will affect the company's operational activities. These operational activities will affect the revenue that will be obtained by the company. The revenues will be deducted from the cost of goods sold and operating expenses or other charges until the profit or loss is earned. In other words, this working capital management affects the company's ability to generate profit (profitability). Companies that are said to have a high level of profitability means high efficiency of the use of working capital used by the company.

To establish working capital in the form of cash, receivables, inventories and other current assets, appropriate analysis is required and has a low level of risk in order to utilize the working capital can be utilized effectively. If the amount of working capital set out not in accordance with the needs of the company, whether excessive or deficient, will produce a negative impact. Excessive working capital, especially in the form of cash and cash equivalents can harm the company because it will cause the amount of funds that accumulate in the balance sheet, thus reducing the level of productivity of the asset.

Besides, the excess of working capital will also enable the company less efficient in running its operations because it can trigger waste. Lack of working capital will also have a negative impact for the company, but will disrupt the liquidity of the company, the

Yuli Anwar: The Effect of Working Capital Management on Profitability in Manufacturing Company Listed in Indonesia Stock Exchange 
company's daily operational activities will also be hampered. Stalled operational activities will disrupt the production process and sales of the company so that the profitability of the company will also be disrupted. The effectiveness of working capital can be measured by using several working capital ratios. Working capital ratio is used to measure the adequacy of the amount of working capital owned by a company. By using the working capital ratio can be known the value of the adequacy of current assets such as cash, accounts receivable, and inventory. Some working capital ratios that can be used include cash turnover ratio, average collection period, and inventory turnover. The turnover of working capital starts from when cash is invested in the working capital component until it becomes cash again. The faster the turnover period of working capital, the faster the rotation so that the velocity of working capital is higher and the more effective the company ultimately profitability.

\section{LITERATURE REVIEW}

\section{A. Profitability}

Profitability by Riyanto (2011) is the company's ability to generate profit over a certain period. While Sartono (2010) defines profitability is the ability of companies to earn profits in relation to sales, total assets and own capital. Every company is always trying to improve profitability. If the company managed to improve profitability, it can be said that the company is able to manage its resources effectively and efficiently so as to generate high profits. Conversely, a company has a low profitability indicates that the company is not able to manage its resources well, so as not to generate high profits. Anwar (2016), revealed that comparing financial report substantial between private and government sector showed that there were no differences between the health levels of government-owned banks and national private sector.

How to assess the profitability of a company is varied depending on the profit and assets or which model will be compared with each other, according to Sawir (2008) revealed that the profitability ratio or profitability ratio can be divided into five types, namely: Gross Profit Margin (Gross Profit Margin - GPM), Net Profit Margin (NPM), Return On Equity (ROE), and Return on Investment (ROI). Gross Profit Margin (GPM) serves to measure the rate of return gross profit to net sales. GPM can be known with the following calculations (Riyanto, 2011): GPM = Gross Profit / Net Sales. Gross profit is net sales minus cost of goods sold, net sales is total net sales for one year. GPM values are between 0 and 1. The GPM value is getting closer to one, hence the more efficient the cost incurred for the sale and the greater the profit return.

Net Profit Margin (NPM) serves to measure the net return on net sales (Riyanto, 2011): NPM = Net Income after Tax / Net Sales. The value of NPM is also between 0 and 1 , the bigger one, the more efficient the cost and the greater the net return.

Return on Equity (ROE) represents the rate of return on the owner's equity. Owner's equity is the total net assets of the company. Return on equity or return on net worth measures the ability of a firm to make a profit available to its shareholders. ROE can be known by the following calculation (Sartono, 2010): ROE = Net Income After Tax / Equity. Return on Investment or return on assets shows the ability of the company to generate profits from the assets used. By knowing this ratio, it can be seen whether the company is efficient in utilizing its assets in the company's operational activities. This ratio also gives a better measure of the company's profitability because it shows the effectiveness of management in using assets to generate revenue (Munawir, 2010): $\mathrm{ROI}=$ Net Income After Tax / Total Assets. Based on the explanation, the hypothesis that can be submitted is: 
$\mathrm{H}_{1}$ : Cash turnover, average collection period, and inventory turnover influence to return on investment.

\section{B. Working Capital}

Working capital is the overall current assets owned by the company, or it may also be intended as a fund that must be available to finance the day-to-day operations of the company (Sawir, 2008). Working capital according to Munawir (2010) is the excess value of assets owned by the company against all its debts. Sartono (2010) explains that there are two terms of working capital, the first gross working capital is the overall current assets, while net working capital is the excess of current assets above the current debt.

From the above understanding it can be concluded that working capital is the company's investment in short-term assets in the form of cash, securities, receivables and inventories used to meet the company's operations.

To determine the amount of working capital that is considered sufficient for a company is not an easy thing, because working capital required by a company is influenced by several factors as follows (Munawir, 2010): From the above understanding it can be concluded that working capital is the company's investment in short-term assets in the form of cash, securities, receivables and inventories used to meet the company's operations.

To determine the amount of working capital that is considered sufficient for a company is not an easy thing, because working capital required by a company is influenced by several factors as follows (Munawir, 2010):

1. Nature or type of company

The need for working capital depends on the type and nature of the business run by a company. Working capital of service companies is relatively lower when compared to the working capital needs of industrial companies, because for service companies do not require a large investment in cash, accounts and inventory. The need for cash to pay employees and to finance their operations can be met from income or receipts on the spot, while receivables are usually billed for a relatively short period of time. For industrial companies required greater working capital because the company must make substantial investment in current assets so that companies do not have difficulty in the operation.

2. The time gained for producing the goods to be sold for the working capital needs of a company is directly related to the time required to produce the goods to be sold. The longer the time it takes to produce the goods, the greater the amount of working capital required.

3. Terms of purchase and sale

Terms of credit purchase of merchandise or raw materials will affect the size of working capital. A favorable terms of purchase credit will minimize the need for cash to be invested in inventory and vice versa. In addition, working capital is also affected by terms of sales. The more soft credit (longer credit terms) given to subscriptions will be the greater the need for working capital to be invested in receivables.

4. Inventory turnover rate

The higher the rate of inventory turnover then the amount of working capital invested in the form of inventory (goods) will be lower. In order to achieve high turnover, efficient inventory planning and supervision must be performed. The higher the inventory turnover rate will reduce the risk of losses caused by 
price reductions or changes in consumer tastes, in addition to saving the cost of storage and maintenance of the inventory.

5. Account receivable turnover rate

The need for working capital is also influenced by the period of collection of accounts receivable. If receivables are accumulated in the short term, the need for working capital is lower or lower. To achieve high receivable turnover rate requires effective oversight of accounts receivable and appropriate discretion with respect to credit expansion, credit terms of sale, maximum credit for subscriptions and collection of accounts receivable.

6. Sales Volume

Companies need working capital to support operational activities in the event of increased sales. If the selling rate is high then the required working capital is relatively high, otherwise when low sales require low working capital.

\section{Season Factors and Cycles}

Fluctuations in sales caused by seasonal and cycle factors will affect the need for working capital. Companies that are affected by the season require a relatively short amount of working capital. Working capital invested in inventory gradually increased in the months leading up to peak sales.

\section{Cash Turnover}

Cash is the most liquid asset or is one of the highest working capital elements of liquidity which means that the greater the amount of cash owned by a company will be the higher the level of liquidity. This means that the company has a smaller risk of not being able to meet its financial obligations. But this does not mean that the company must maintain a very large cash supply, because the greater the cash will cause the amount of money idle so that it will reduce its profits. But a company that only pursues profit without regard to liquidity, then the company will be in a state of liquid if at any time there is a bill (Riyanto, 2011).

Riyanto, B (2011), the higher the cash flow means the cash backs to the company. Thus, cash will be used again to finance the company's operational activities so as not to disrupt the company's financial condition. Based on the explanation, the hypothesis that can be submitted is:

$\mathrm{H}_{2}$ : Cash turnover influence to return on investment.

\section{Average Collection Period}

Accounts receivable is one way to increase the level of sales, but not necessarily then the receivables become unnecessary to be controlled. To control the accounts receivable, the company needs to establish its credit policy. This policy then serves as the standard of any credit to be given to the consumer. Benefits earned by selling on credit are additional profits, while the sacrifice is an additional cost of funds.

According to Munawir (2010) the period of collection of receivables is a number indicating the average time required to collect receivables. Management should be able to manage accounts receivable properly. Analyzing accounts receivable is very important for management in order to properly manage accounts receivable. One way to analyze receivables is to use the average collection period collection method. The average collection period of receivables is the time it takes for a company to collect its receivables. Based on the explanation, the hypothesis that can be submitted is:

$\mathrm{H}_{3}$ : Average collection period influence to return on investment. 


\section{E. Inventory Turnover}

Inventory or inventory of goods as the main element of working capital is an asset that is always in a state of rotation, where it is constantly changing. The investment problem in inventory is an issue of active spending, as do investments in other assets. The problem of determining the amount of investment or allocation of capital in inventory has a direct effect on corporate profits. Mistakes in determining the amount of investment in inventory will reduce the company's profits. The presence of an investment in inventory that is too large compared to the need to increase interest expenses, increase storage and maintenance costs in the warehouse, increase the likelihood of losses due to damage, decline in quality, so that all this will minimize the benefits of the company. In contrast, too little investment in inventory will also have an effect on the company's profits (Riyanto, 2011).

Inventory turnover shows how many times the funds that are embedded in the inventory rotate within a period. The higher the inventory turnover rate then the amount of working capital needed (especially those that must be invested in inventory) is lower. The higher the inventory turnover rate will minimize the risk of losses caused by price reductions or due to changes in consumer tastes, in addition to saving the cost of storage and maintenance of the inventory. Based on the explanation, the hypothesis that can be submitted is:

$\mathrm{H}_{4}$ : Inventory turnover influence to return on investment.

\section{F. Conceptual Framework}

This study will discuss the effect of working capital which includes cash turnover, receivable collection period and inventory turnover on profitability. Based on the study of theory or concept of profitability and working capital management, as well as some previous research is known there are some working capital variables that affect profitability, the variables in this study is the ROI as dependent variable and cash turnover, the average collection period receivables and inventory turnover as an independent variable. The systematic framework conceptual in this research can be seen in the following picture:

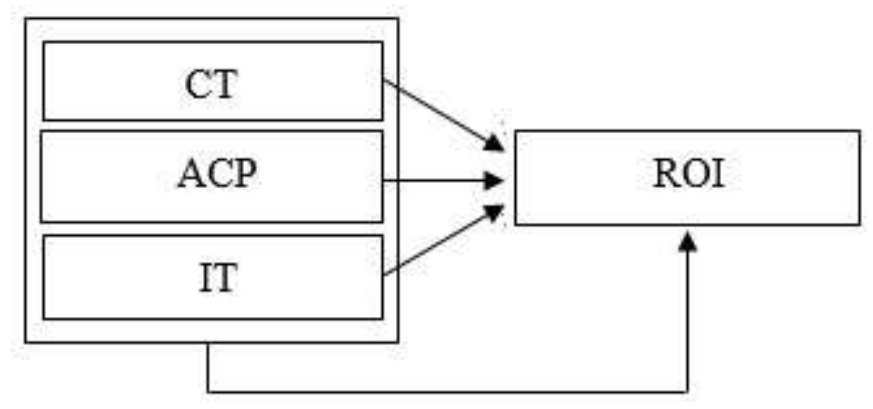

Figure 1. Conceptual Framework

Where :

CT : Cash Turnover

ACP : Average Collection Period

IT : Inventory Turnover

ROI : Return On Investment 


\section{METHOD}

\section{A. Sample and Procedure}

The data used in this study is secondary data in the form of annual financial statements of manufacturing companies listed on the Jakarta Stock Exchange. and has been published, such as: data from Indonesia Stock Exchange (IDX), Journal, internet www.idx.co.id, www.sahamok.com, and the company website concerned.

The financial statements used in this study are the financial statements with the end of the year of bookkeeping as of December 31, 2011, 2012, 2013, 2014, and 2015 from manufacturing companies of the consumer goods industry sector listed on the Stock Exchange. So the data used is a type of cross-section data is data that shows a particular point in time.

To obtain secondary data in the form of annual financial report of manufacturing company of consumer goods industry sector listed on IDX, researcher use documentation technique that is collecting secondary data in the form of annual report from Financial Performance Summary year 2011-2015. Data obtained by using internet media by downloading report finance of consumer goods industry manufacturing companies listed on the Indonesia Stock Exchange for the period 2011, 2012, 2013, 2014, and 2015 through the official website of Indonesia Stock Exchange namely www.idx.co.id, www.sahamok.com, and the company website concerned.

The population in this research are all manufacturing companies of consumer goods industry sector listed on IDX for period 2011 to 2015 consisting of five subsectors namely food and beverage sub-sector, cigarette sub-sector, pharmaceutical sub-sector, cosmetics sub sector and household goods, and home appliance sub-sector. The sample in this study was chosen based on certain criteria. These criteria are: (1) A manufacturing company in the sector of listed consumer goods industry (listing) in Indonesia Stock Exchange (IDX) which publishes and publishes annual financial reports in full and has been audited during $2011-2015$ period, (2) the consumer goods industry that performs mergers and acquisitions during 2011-2015, and (3) manufacturing companies in the consumer goods industry sector which generated negative profits during the period 2011-2015. Based on the above criteria, the companies that meet the requirements as the sample in this study are 23 company.

\section{B. Data Analysis}

Based on the title, background, and problem formulation, the data analysis is done by statistical test using Statistical Package for Social Science (SPSS) 20. Based on the purpose and hypothesis expressed in this research, the data analysis method that can be applied is regression analysis multiple. Judging from this type of research which is a correlation research, data analysis method by applying multiple regression analysis into a choice that should be used. Through this analysis can be seen the influence or relationship between independent variables (independent variable) with dependent variable (dependent variable). With multiple regression analysis it can be seen how big working capital (working capital turnover, cash, accounts receivable and inventory) which is independent variable have an effect on profitability $(\mathrm{ROI})$ as dependent variable. The multiple regression equation used in this research are:

$$
Y=\beta_{0}+\beta_{1} X_{1}+\beta_{2} X_{2}+\beta_{3} X_{3}+e_{i}
$$

The classical assumption test conducted in this study aims to test the data used in this study whether it has met the classical assumption, that is normal distributed data, no multicolinearity symptoms, no autocorrelation and no symptoms 
of heteroscedasticity. If it has fulfilled these four things then the regression model will give the result of Best Linear Unbiased Estimator (BLUE), (Ghozali, 2011). To test the classical assumption in this research, researchers use SPSS 20 computer program. Normality test aims to test a regression model, independent variable, dependent variable, or both have a normal distribution or not. A good regression model is a normal or near-normal distribution.

According to Ghozali (2011), normality can be detected by looking at the spread of data (dots) on the diagonal axis of the graph or by looking at the histogram of the residue. Basic decision-making (1) if the data spreads around the diagonal line and follows the direction of the diagonal line or histogram graph shows the normal distribution pattern, then the regression model meets the assumption of normality. (2) if the data spreads far from the diagonal line and or does not follow the diagonal line or the histogram graph does not show the normal distribution pattern then the regression model does not meet the assumption of normality.

The statistical test used to test residual normality is Kolmogorov-Smirnov nonparametric statistical test (K-S). According to Ghozali (2011), Kolmogorov-Smirnov test is done by making a hypothesis:

$\mathrm{H}_{0} \quad$ : The residual data is normally distributed, if sig. 2-tailed $>\alpha=0.05$

$H_{a}$ : Residual data is not normally distributed, if sig. 2-tailed $<\alpha=0.05$

Multicollonearity test aims to test whether the regression model found a correlation between independent variables (independent). A good regression model should not be correlated between independent variables. If independent variables are mutually correlated, then these variables are not orgonal. Orgonal variable is independent variable which correlation value between fellow independent variable equal to zero (Ghozali, 2011).

There are several ways used to detect multicolonierity, but to detect the presence or absence of multicollinearity in the regression model in this study seen from tolerance value or variance inflation factor (VIF). The selection of tolerance value or variance inflation factor (VIF) in this study because this way is a common way that is performed and considered more reliable in detecting the presence of multicolonierity in the regression model and testing with tolerance value or variance inflation factor (VIF) more complete in analyze the data.

The basis of decision making with tolerance value or variance inflation factor (VIF) can be summarized as follows: (1) if tolerance value $>0.1$ and VIF $<10$, it can be concluded that there is no multicolinearity among independent variables in the regression model. (2) if tolerance value $<0,1$ and VIF $>10$, it can be concluded that there is multicollinearity between independent variables in the regression model.

Autocorrelation test aims to test whether in the linear regression model there is a correlation between the disturbing error in period t with the disturbance error in period t-1 (previous). To detect the presence or absence of autocorrelation in this study used Durbin-Watson test (DW Test), because the number of observations in this study amounted to under 100 that only 95 observations (Ghozali, 2011). Autocorrelation test is done by making hypothesis:

$\mathrm{H}_{\mathrm{o}} \quad$ : There is no autocorrelation

$\mathrm{H}_{\mathrm{a}}$ : There is autocorrelation.

Heteroscedastisity test aims to test whether in the regression model there is a variance inequality of the residual one observation to another observation. If the variance from one observation to another observes remains, then it is called homoscedasticity or does not occur heterokedastisitas. If the variance is different then it is called heteroscedastisity. A good regression model is homoscedasticity or does not occur heteroscedastisity. 
The most common way used to detect the presence or absence of heteroscedasticity is to look at the scatterplot between the predicted value of the dependent variable (ZPRED) with the residual SRESID. Detection of whether or not heteroscedastisity can be done by looking at whether there is a certain pattern on the scatterplot chart between SRESID and ZPRED.

According to Ghozali (2011), the basic analysis to determine whether or not heteroscedastisity with scatterplot are: (1) if there is a certain pattern, such as dots that form a certain pattern, regular (wavy, widened, then narrowed), then indicate heteroscedasticity occurs. If there is no clear pattern, and the points spread above and below the zero on the $Y$ axis, no heteroscedasticity occurs. Analysis with Graph Plots have a significant disadvantage because the number of observations affects ploting results. The less number of observations, the harder it is to interpret the results of the plot graph. To overcome the weakness of the Plots Graph, then in this study will also be tested statistics to ensure the accuracy of test results. The selected statistical test is Glejser test, the basis of decision making of heteroscedasticity test through Glejser test are: (1) if sig. 2-tailed $<\alpha=0.05$, there has been heteroscedasticity and (1) if sig. 2-tailed $>\alpha=0.05$, no heteroscedasticity occurs.

\section{Hypotheses Test}

Testing the truth of the research hypothesis is done through testing the regression model and testing the partial influence of each independent variable. The accuracy of the sample regression function in estimating the actual value can be measured from its goodness of fit. Statistically, at least this can be measured from the coefficient of determination $\left(R^{2}\right)$, the statistical value $F$, and the statistical value $t$. The statistical calculation is called statistically significant if the value of the statistical test is in the critical area (the area where $\mathrm{H}_{0}$ is rejected). Conversely, it is not significant if the value of the statistical test is in the region where $\mathrm{H}_{0}$ is received.

According Ghozali (2011) "The coefficient of determination $\left(R^{2}\right)$ essentially measures how far the model's ability to explain variations of independent variables". A small $R^{2}$ value means the ability of variable-independent variables to explain the variation is very limited, otherwise the value of $R^{2}$ approaching one means the variable-independent variable gives almost all the information needed to predict the variation. Determination coefficient value used in this research is adjusted $R^{2}$ value because independent variable used in this research more than two variable. In addition the adjusted $R^{2}$ value is considered better than the value of $R^{2}$, since the adjusted value of $R^{2}$ can rise or fall if one independent variable is added to the regression model (Ghozali, 2011).

Simultaneously, hypothesis testing is done by F-test. According to Ghozali (2011) "The statistical test F basically shows whether all independent or independent variables included in the model have a joint influence on / bound".

In this research, $\mathrm{F}$ test is used to test the hypothesis of $\mathrm{H}_{4}$, that is the influence of CT, ACP, and IT simultaneously on profitability at manufacturing company of consumer goods industry sector listed on IDX. According to Ghozali (2011), the $\mathrm{F}$ test is done by comparing the significance of Fcount with Ftable with the provisions: 91) $\mathrm{H}_{\mathrm{o}}$ is accepted and $\mathrm{H}_{\mathrm{a}}$ is rejected if $\mathrm{F}$-value $<\mathrm{F}$-table for $\alpha=0,05$ and (2) $\mathrm{H}_{0}$ is rejected and $\mathrm{H}_{\mathrm{a}}$ accepted if $F$-value $>F$-table for $\alpha=0.05$.

Partially, hypothesis testing is done by t-test. According to Ghozali (2011) "The statistical test $t$ basically indicates how far the influence of an individual explanatory / independent variable in explaining". In this research, $t$ test is used to test the hypothesis of $\mathrm{H}_{1}, \mathrm{H}_{2}$, and $\mathrm{H}_{3}$, that is the influence of $C T, A C P$, and IT partially to profitability at manufacturing company of consumer goods industry sector listed on IDX. According to Ghozali (2011), the $t$ test is performed by comparing the significance of tcount with ttable with the following conditions: (1) $\mathrm{H}_{\mathrm{o}}$ is accepted and 
$H_{a}$ is rejected if $t$-value $<t$-table for $\alpha=0,05$ and (2) $H_{0}$ is rejected and $H_{a}$ is accepted if $t$ value $>\mathrm{t}$-table for $\alpha=0.05$.

\section{RESULT}

The result of $F$ test shows that the value of Fvalue is 6,937 . While the Ftable value with $(\mathrm{N}=115, \mathrm{k}=3, \alpha=5 \%)$ is known at 2.68. If the value of $\mathrm{F}$-count is compared F-table then F-count $>$ F-table $=6,937>2,68$. While the significant value (sig.) Is 0,000 when compared with $\alpha=5 \%$ it is obtained $0.000<0.05$. Hence the hypothesis $H_{0}$ rejected and $\mathrm{H}_{\mathrm{a}}$ accepted, this means simultaneously $\mathrm{CT}, \mathrm{ACP}$, and IT have a significant influence on the ROI in the manufacturing industry sector of consumer goods industry listed on the Stock Exchange during the period 2011-2015.

\section{$Y=2,028+0,184 C T-0,477$ ACP $-0,001 I T+e$}

In the above summary model it can be seen that the adjusted value of $R^{2}$ is 0.135 . This means that $13.5 \% \mathrm{ROI}$ can be explained or influenced by the independent variables used in this research, namely Cash Turnover (CT), Average Collection Period (ACP) and Inventory Turnover (IT). While the rest $(100 \%-13.5 \%=86.5 \%)$ ROI influenced by other factors that are not contained in the model of regression equation in this study.

\section{A. Cash Turnover Influence to Return on Equity}

Significant partial test results (t-test) shows that CT affects the profitability of manufacturing companies in the consumer goods industry sector listed on the Stock Exchange. The proof that this variable has a significant influence is indicated by the degree of significance that is below 0.05 of 0.02 . Thus $H_{0}$ is rejected and $H_{1}$ is accepted. The results of this study support the results of research obtained Rahma (2011) on manufacturing companies for the period 2004 to 2008, Satriya and Lestari (2014) in the company Property and Real Estate period 2009 - 2011. On the other hand the results of this study contrary to the results obtained research Kautsari (2014) in the tobacco companies listed on the IDX for the period 2005 - 2011 stating if the cash turnover negatively affects the ROI.

The existence of a positive influence means that the higher the cash turnover then the profits obtained by the company will also be higher. With a certain amount of cash owned by the company, will generate high sales. A high level of sales will lead to higher corporate profits. This shows the company has been using cash efficiently.

\section{B. Average Collection Period (ACP) to Profitability (ROI)}

Significant partial test results (t-test) shows that ACP has an effect on profitability in manufacturing companies of consumer goods industry sector listed on IDX. The proof that this variable has a significant influence is indicated by the degree of significance that is below 0.05 that is equal to 0.00 . Thus $\mathrm{H}_{\mathrm{o}}$ is rejected and $\mathrm{H}_{2}$ is accepted. The results of this study are in line with the results of research Kautsari (2014) on tobacco companies listed on the IDX for the period 2005-2011 and Irsutami (2014) on the company Property and Real Estate Go Public in IDX Year 2006 - 2011. On the other hand research results this is in contrast to research results obtained by Ismanto (2013) on Ceramic Entrepreneurs at Ceramics Center in Banjarnegara which states if ACP has no significant effect on ROI.

This significant negative relationship means that when companies shorten the period of receivables then the profitability of the firm will increase significantly. Vice versa, the longer the collection period will decrease the company's profitability. The collection period of accounts receivable is a number indicating the average time required to collect a receivable. The number of days of sales in receivables gives a benchmark on the length of time the accounts receivable are outstanding. The sooner

Yuli Anwar: The Effect of Working Capital Management on Profitability in Manufacturing Company Listed in Indonesia Stock Exchange 
a company receives a receivable payment from a sales agent or distributor, the company will be able to reduce the risk of uncollectible receivables and accelerate cash (cash) that can be used for debt repayment, operational funding, and profitable business opportunities. When a company customer delays its debt payments, the company will have a larger billing period. Therefore the company must establish a billing policy.

\section{Inventory Turnover (IT) to Profitability (ROI)}

Significant partial test results (t-test) shows that IT does not affect the profitability of manufacturing companies in the sector of consumer goods industry listed on the Stock Exchange. The proof that this variable has an insignificant influence is indicated by the degree of significance that is above 0.05 that is equal to 0.996. Thus $\mathrm{H}_{0}$ is accepted and $\mathrm{H}_{3}$ is rejected.

The results of this study support the results of research obtained Rahma (2011) on manufacturing companies listed on the Stock Exchange for the period 2004 - 2008 stating that if the inventory turnover does not affect the profitability. On the other hand, the results of this study contradict the results obtained by Satriya and Lestari (2014) at the property and real estate company for the period of 2009-2011, Kautsari (2014) in the cigarette company listed on the IDX for the period 2005-2011 stating that inventory turnover has a significant effect on profitability.

\section{E. Discussion}

Main Findings

1. Simultaneously, the results showed that working capital variables consisting of CT (Cash Turnover), ACP (Average Collection Period), and IT (Inventory Turnover) have significant effect on profitability (Return on Inventment) in manufacturing sector of consumer goods sector for the year 2011 - 2015 listed on the Indonesia Stock Exchange, where 13\% profitability is influenced by the independent variables used in this study with a 95\% confidence level.

2. Partially significant test result (t-test) shows that partially Cash Turnover (CT) has a significant effect on profitability in consumer goods manufacturing sector company period 2011-2015 listed in Indonesia Stock Exchange.

3. Partial significant test result (t-test) shows that partially Average Collection Period (ACP) has a significant effect on profitability in consumer goods manufacturing sector company period 2011 - 2015 listed in Indonesia Stock Exchange.

4. The result of partial significant test ( $t$ test) shows that partially Inventory Turnover (IT) has no effect on profitability in consumer goods manufacturing sector in 2011 - 2015 which is listed in Indonesia Stock Exchange.

\section{E. Limitation}

Some limitations of this research may also be used to develop the future similiar research. The limitation are as follows:

1. This study does not consider the ability of the size effect. Company size affects the company's ability to earn a profit.

2. This study only examines some of the variables including the working capital component so that more to prove the factors affecting profitability can be used other variables. 


\section{CONCLUSION}

Subsequent research should use other variables that are not used in this study because the influence of independent variables in this study on profitability only $13 \%$, therefore the next research is expected to add other variables that may affect profitability in addition to variables in this study. Research samples can be extended not only to manufacturing companies but also to other types of firms with longer observation periods so that the results obtained will represent the real object of research and add macroeconomic factors such as inflation rate, growth economic, government policies and the political and economic conditions of a country.

\section{REFERENCES}

Anwar, Y. 2016. Comparative analysis of commercial banks government owned and private banks national using RGEC, The Accounting Journal of Binaniaga, Vol. 01 No. 1, pp. 27-36.

Anwar, Y. and Etty, M. 2017. Tthe effect of credit risk and capital adequacy ratio upon return on asset (a case study at banking listed in indonesia stock exchange), The Accounting Journal of Binaniaga, Vol. 02 No. 2, pp. 23-38.

Ghozali, I. 2011. Application of multivariate analysis with SPSS software, Semarang: Badan Penerbit Universitas Diponegoro.

Irsutami, Y. S. S. 2014. Analysis of effect of working capital management on profitability (case study on property and real estate companies listed on Indonesia stock exchange years of 2006-2011). Script Journals, Politeknik Negeri Batam.

Ismanto, A. L. I. 2013. Effect of working capital management on profitability (a case study on ceramic entrepreneurs at ceramic craft centers in Banjarnegara). Script Journals, Universitas Negeri Semarang.

Kautsari, R. K. B. 2014. Effect of work capital management on profitability of companies in cigarette companies listed in Indonesia stock exchange. Script Journals, Faculty of Economics University of Brawijaya.

Mardiyanto, H. 2009. Essence of financial management. Jakarta: PT Grasindo.

Munawir, S. 2010. Analysis of financial management, Fourth Edition. Yogyakarta: Liberty.

Rahma, A. 2011. Analysis of effect of working capital management on corporate profitability (study on PMA and PMDN manufacturing companies listed on Indonesia stock exchange periode 2004-2008). Script Journals, Faculty of Economics University of Diponegoro.

Riyanto, B. 2011. Company spending basics. Yogyakarta: BPFE.

Sartono, A. 2010. Financial management: theory and application, Fourth Edition, Yogyakarta: BPFE.

Satriya, I. M. D. and Putu, V. L. 2014. The influence of working capital turnover to company profitability. Script Journal, Faculty of Economics and Business University of Udayana.

Sawir, A. 2008. Financial performance analysis and financial planning company. Jakarta: Gramedia Pustaka Utama.

Yuli Anwar: The Effect of Working Capital Management on Profitability in Manufacturing

Company Listed in Indonesia Stock Exchange 
The Accounting Journal of BINANIAGA Vol. 03, No. 01, June 2018

PISSN: $2527-4309$

EISSN: $2580-1481$

Sugiyono. 2014. Business research methods. Bandung: CV Alfabeta.

Weston, F. J. C. 2009. Financial management. Jakarta: Kina Rupa Aksara. 